\title{
UJI EFEK ANTELMINTIK EKSTRAK ETANOL DAUN PINANG YAKI (Areca vestiaria) TERHADAP CACING GELANG (Ascaris lumbricoides) SECARA IN VITRO
}

\author{
Tirza N. E. Roring1), Herny E. I. Simbala ${ }^{1)}$, Edwin de Queljoe ${ }^{2)}$ \\ ${ }^{1)}$ Program Studi Farmasi FMIPA UNSRAT Manado, 95115 \\ ${ }^{2)}$ Jurusan Biologi FMIPA UNSRAT Manado, 95115
}

\begin{abstract}
Pinang Yaki (Areca vestiaria) is an endemic species of Sulawesi palm, which has unique characteristics that have been used as medicine, to treat various. Ethanol extracts of pinang yaki leaves contains tannin compounds that can inhibit the work of enzymes, interfere with digestive metabolic processes, and damage the worm cell membrane. This study aims to determine the anthelmintic effect of ethanol extract of pinang yaki leaves obtained from the Tomohon area against roundworms (Ascaris lumbricoides). The sample was extracted by maceration method using ethanol solvent. The test used ethanol extracts $f$ pinang yaki leaves with a concentration of 5\%, $10 \%$, and $20 \%$, respectively. The worms were incubated at a temperature of $37^{\circ} \mathrm{C}$, and examined for 24 hours at 6 hour intervals. The number of lysis worms and paralysis was recorded every 6 hours and the data were analyzed using the Kruskal Wallis test and continued using the Mann Whitney test. The results showed an anthelmintic effect of ethanol extracts of pinang yaki leaves on roundworms (Ascaris lumbricoides) in vitro.
\end{abstract}

Keywords : : Anthelmintic, Ethanol extracts of areca leaf, Areca vestiaria, Ascaris lumbricoides

\begin{abstract}
ABSTRAK
Pinang Yaki (Areca vestiaria) merupakan jenis palem endemik Sulawesi yang memiliki karakteristik yang unik telah dimanfaatkan sebagai obat, untuk mengobati berbagai penyakit. Ekstrak etanol daun pinang yaki mengandung senyawa tanin yang dapat menghambat kerja enzim, mengganggu proses metabolisme pencernaan, serta merusak membran sel cacing. Penelitian ini bertujuan untuk mengetahui adanya efek antelmintik dari ekstrak etanol daun pinang yaki yang diperoleh dari daerah Tomohon terhadap cacing gelang (Ascaris lumbricoides). Sampel diekstraksi dengan metode maserasi menggunakan pelarut etanol. Metode penelitian ini ialah eksperimen laboratorium dengan desain post test only control group. Pengujian menggunakan ekstrak etanol daun pinang yaki dengan konsentrasi 5\%,10\%, dan $20 \%$. Cacing diinkubasi pada suhu $37^{\circ} \mathrm{C}$, dan diteliti selama 24 jam dengan interval waktu 6 jam. Jumlah cacing lisis dan paralisis dicatat setiap 6 jam dan selanjutnya data dianalisis menggunakan uji Kruskal Wallis dan dilanjutkan menggunakan uji Man Whitney. Hasil penelitian menunjukkan adanya efek antelmintik dari ekstrak etanol daun pinang yaki terhadap cacing gelang (Ascaris lumbricoides) secara in vitro.
\end{abstract}

Kata kunci : Antelmintik, Ekstrak Etanol Daun Pinang Yaki, Areca vestiaria, Ascaris lumbricoides 


\section{PENDAHULUAN}

Cacing (Helminths) adalah golongan hewan yang mempunyai banyak sel multiseluler dan dengan tubuh yang bentuknya simetris bilateral. Filum cacing terbagi atas filum Platyhelminthes dan filum Nemathelminthes. Terdapat 2 kelas dalam filum Platyhelminthes, yaitu kelas Cestoda dan kelas Trematoda, sedangkan filum Nemathelminthes, yaitu kelas Nematoda yang dapat menyebabkan penyakit pada manusia maupun hewan. Cacing Nematoda yang menginfeksi manusia, tergantung pada spesiesnya (Soedarto, 2011). Salah satu cacing yang sering menginfeksi yaitu cacing gelang (Ascaris lumbricoides) yang terdapat dalam usus hewan ternak babi. Peternakan babi di beberapa negara berkembang dengan iklim tropis dan sub tropis mengalami kendala penyakit cacing, karena perkembangan telur cacing menjadi larva infektif dapat berlangsung sepanjang tahun (Syukron et al., 2014).

Cacingan merupakan masalah kesehatan masyarakat yang masih tersebar luas di seluruh dunia. Terutama di negara-negara berkembang dengan PHBS dan sanitasi yang buruk. Dilaporkan bahwa lebih dari $24 \%$ populasi dunia terinfeksi cacingan dan $60 \%$ diantaranya adalah anak-anak (WHO, 2015). Morbiditas akibat penyakit cacingan berhubungan dengan jumlah cacing yang menginfeksi tubuh. Infeksi yang ringan belum menimbulkan gejala, sedangkan infeksi yang lebih berat dapat menyebabkan beberapa gejala berupa diare, sakit perut, lesu, kelemahan, gangguan kognitif dan perkembangan fisik (WHO, 2016).

Penyakit yang disebabkan oleh cacing ini terjadi karena sanitasi di lingkungan sekitarnya kurang terpelihara dengan baik. Penyakit yang disebabkan oleh infeksi cacing dapat menurunkan kualitas hidup penderitanya, diantaranya mengakibatkan kurang darah atau anemia, obstruksi usus, berkurangnya nafsu makan, diare, gangguan penyerapan nutrisi dan gangguan perkembangan anak. Anak yang mempunyai penyakit ini mempunya risiko
$3-7$ kali bertubuh kecil atau kerdil dan $1-5$ kali menjadi kurang gizi. Sehingga pembasmian penyakit cacing ini sangat perlu, agar tidak mempengaruhi tumbuh kembang pada penderita (Kazura, 2007).

Antelmintik adalah obat yang digunakan untuk memberantas dan mengurangi cacing dari dalam tubuh manusia atau hewan (Tjay dan Rahardja, 2002). Pada kondisi-kondisi tertentu penanganan antelmintik dengan obat-obat sintetik tidak dapat diberikan. Salah satu contohnya pada penggunaan mebendazol sebagai antelmintik sangat terbatas untuk penderita askariasis. Hal tersebut karena penderita askariasis yang memiliki kelainan hati ataupun ginjal, karena antelmintik ini dimetabolisme dalam hati dan dieksresikan melalui ginjal (Katzung, 2004).

Obat-obat yang digunakan selama ini untuk penyakit cacing adalah obat-obat kimia yang memiliki efek samping tidak baik bagi kesehatan. Perkembangan lebih lanjut perlu dicari dan diteliti obat cacing lain sebagai terapi alternatif untuk memberantas penyakit cacingan yaitu tumbuhan obat yang dapat digunakan (Nuryani, 2014). Obat tradisional merupakan salah satu alternatif untuk mengobati infeksi cacing karena dinilai lebih aman, lebih murah, mudah dibeli, dan efek sampingnya relatif lebih ringan disbanding dengan obat sintetik (Ningsih, 2016).

Hasil penelitian bioekologi yang sudah dilakukan, pinang yaki (Areca vestiaria) merupakan jenis palem endemik Sulawesi yang memiliki karakteristik yang unik dan merupakan salah satu komponen penting dalam ekosistem hutan hujan tropis. Oleh masyarakat sekitar Taman Nasional Bogani Nani Wartabone (TNBNW) pinang yaki (Areca vestiaria) telah dimanfaatkan sebagai obat, untuk mengobati berbagai penyakit (Simbala, 2007).

Pada tanaman pinang yaki terdapat senyawa tanin yang bersifat antelmintik. Tanin menghambat kerja enzim dan mengganggu proses metabolisme pencernaan pada cacing sehingga cacing akan kekurangan nutrisi 
akhirnya menyebabkan kematian pada cacing (Hamzah et al., 2016). Selain itu kemampuan daya antelmintik dari senyawa tanin yaitu dengan merusak membran, membran cacing yang rusak karena tanin menyebabkan cacing paralisis yang akhirnya mati (Tiwow, 2013).

\section{METODOLOGI PENELITIAN}

\section{Alat}

Alat yang digunakan: Ayakan 100 mesh, evaporator, inkubator, batang pengaduk, pinset, cawan petri, corong, gelas ukur (Pyrex), gelas beker (Pyrex), kertas saring, sarung tangan lateks, masker (SENSI Mask), gunting, blender, timbangan analitik, timbangan biasa, toples kaca, hot plate, tissue, kertas wrap, kertas label.

\section{Bahan}

Bahan yang digunakan: ekstrak etanol daun pinang yaki (Areca vestiaria), aquades steril, etanol 96\%, $\mathrm{NaCl} 0,9 \%$, tablet Combantrin ${ }^{\circledR} 250 \mathrm{mg}$, cacing gelang (Ascaris lumbricoides).

\section{Pengambilan dan Penyiapan Sampel}

Tahap awal dilakukan dengan pengumpulan sampel daun pinang yaki yang diambil di daerah Tomohon. Kemudian daun pinang yaki dibawa ke Laboratorium Penelitian Program Studi Farmasi Fakultas Matematika dan Ilmu Pengetahuan Alam Universitas Sam Ratulangi Manado. Selanjutnya daun pinang yaki dicuci bersih dengan air mengalir, ditiriskan dan ditimbang berat basahnya sehingga dapat diketahui berat basah dari daun pinang yaki tersebut yaitu $7 \mathrm{~kg}$. Daun yang telah dibersihkan dikering-anginkan di dalam ruangan selama 1 minggu. Daun yang telah kering diblender sampai menjadi halus dan diayak menggunakan ayakan mesh 100 .

\section{Ekstraksi}

Daun Pinang Yaki sebanyak $1 \mathrm{~kg}$ yang sudah diayak selanjutnya diekstraksi dengan cara maserasi. Daun pinang yaki yang sudah menjadi serbuk dimasukkan ke dalam 2 bejana dan dibagi masing-masing bejana berisi $500 \mathrm{~g}$ sampel, kemudian masing-masing sampel dalam bejana direndam dengan pelarut etanol sebanyak 2,5 L sampai sampel terendam semuanya dan dibiarkan selama 5 hari, sambil berulang-ulang diaduk setiap hari, kemudian disaring menggunakan kertas saring. Selanjutnya diremaserasi dengan pelarut etanol sebanyak 1,5 L sampai terendam semuanya dan dibiarkan selama 2 hari, sambil berulang-ulang diaduk setiap hari. Kemudian sampel tersebut disaring menggunakan kertas saring. Setelah itu filtrat yang diperoleh, dipekatkan menggunakan evaporator dengan suhu $40^{\circ} \mathrm{C}$ sampai diperoleh ekstrak kental, dan selanjutnya ditimbang menggunakan timbangan analitik.

\section{Pengambilan Hewan Uji}

Cacing gelang (Ascaris lumbricoides) diambil dari usus hewan ternak babi di salah satu pasar tradisional kota manado yaitu pasar karombasan, kemudian cacing dimasukkan dalam wadah yang disiapkan, dan berisi larutan $\mathrm{NaCl}$ 0,9\%.

\section{Perlakuan terhadap Hewan Uji}

Metode penelitian ini ialah eksperimen laboratorium dengan desain post test only control group. Pada penelitian ini populasi cacing yang digunakan adalah cacing gelang (Ascaris lumbricoides). Dan sampel yang digunakan sebanyak 45 ekor dengan kriteria inklusi yaitu cacing yang masih aktif bergerak. Berat ekstrak yang digunakan untuk mendapat konsentrasi ekstrak yang ditentukan menggunakan perhitungan berat per volume $(\mathrm{b} / \mathrm{v})$ :

$$
\mathrm{b} / \mathrm{v}=\frac{\text { berat } \text { zat terlarut }}{\text { volume pelarut }} \times 100 \%
$$

Sampel dibagi dalam 5 kelompok, yaitu: a. Kelompok I: terdiri atas cacing gelang (Ascaris lumbricoides) + ekstrak etanol daun pinang yaki 5\%. 
b. Kelompok II: terdiri atas cacing gelang (Ascaris lumbricoides) + ekstrak etanol daun pinang yaki $10 \%$.

c. Kelompok III: terdiri atas cacing gelang (Ascaris lumbricoides) + ekstrak etanol daun pinang yaki $20 \%$.

d. Kelompok IV: diberi obat sintetik yaitu larutan tablet Combantrin® $250 \mathrm{mg}$ sebagai kontrol positif.

e. Kelompok V: diberi larutan $\mathrm{NaCl}$ 0,9\% sebagai kontrol negatif.

$$
\text { Selanjutnya replikasi dilakukan }
$$

sebanyak 3 kali agar dapat menjaga reliabilitasnya. Dalam setiap kelompok terdapat 3 ekor cacing yang direndam di dalamnya. Prosedur Percobaannya adalah sebagai berikut:

1) Cawan petri disiapkan, masing-masing berisi ekstrak etanol daun pinang yaki, larutan tablet pirantel pamoat, dan $\mathrm{NaCl}$ 0,9\% sesuai konsentrasi masing-masing.

2) Cacing gelang (Ascaris lumbricoides) sebanyak 3 ekor dimasukkan kedalam masing-masing cawan petri, kemudian diinkubasi pada suhu $37^{\circ} \mathrm{C}$, dan diteliti selama 24 jam dengan interval waktu 6 jam.

3) Cacing diusik dengan batang pengaduk untuk mengetahui apakah cacing lisis atau mati, paralisis, atau masih normal setelah diinkubasi, jika cacing diam, dipindahkan ke dalam air panas dengan suhu $50^{\circ} \mathrm{C}$, apabila dengan cara ini cacing tetap diam berarti cacing tersebut telah lisis, tetapi jika bergerak berarti cacing itu hanya paralisis

4) Hasil yang diperoleh dicatat. Batasan lisis dalam percobaan ini adalah bila cacing mati atau cacing tidak bergerak bila dimasukkan ke dalam air panas dengan suhu $50^{\circ} \mathrm{C}$.

\section{Analisis data}

Data yang dikumpulkan dalam penelitian ini adalah data deskriptif yang didapat dari jumlah cacing yang lisis dan jumlah cacing yang paralisis sesuai dengan interval waktu pengamatan yang ditentukan pada tiap kelompok uji. Selanjutnya analisis menggunakan uji Kruskal Wallis untuk mengetahui ada atau tidaknya perbedaan efek dari kelompok perlakuan, kontrol positif, dan kontrol negatif. Kemudian dilanjutkan dengan uji Mann Whitney, untuk membandingkan perbedaan efek antara kelompok perlakuan dan kelompok kontrol.

\section{HASIL DAN PEMBAHASAN}

Dalam penelitian ini dilakukan pengamatan selama 24 jam dengan interval waktu 6 jam untuk mengetahui ada atau tidaknya efek antelmintik dari ekstrak etanol daun pinang yaki yaitu dengan mengamati cacing gelang (Ascaris lumbricoides) sebagai hewan uji mengalami lisis atau hanya paralisis saat terendam dengan larutan ekstrak etanol daun pinang yaki. Dalam interval waktu tersebut dilakukan pengamatan keadaan dari cacing tersebut apakah lisis, paralisis, atau masih normal. Untuk memastikan setiap keadaan tersebut, cacing diusik menggunakan batang pengaduk pada interval waktu yang telah ditentukan saat cacing tersebut terlihat tidak bergerak atau hanya diam. Jika cacing tersebut tetap tidak bergerak atau hanya diam saat diusik maka akan dilanjutkan dengan memasukkannya ke dalam air dengan suhu $50^{\circ} \mathrm{C}$.

Penelitian ini berlangsung selama 8 hari, tapi tidak dilakukan secara berturut karena adanya keterbatasan untuk memperoleh hewan uji yang tidak sering didapatkan. Pengujian ini terbagi atas 5 kelompok yaitu kelompok 1 diberi perlakuan dengan ekstrak yang terdiri dari konsentrasi 5\%, kelompok 2 ekstrak dengan konsentrasi $10 \%$, kelompok 3 ekstrak dengan konsentrasi 20\%, kelompok 4 disebut sebagai kontrol positif yang terdiri dari larutan tablet Combantrin ${ }^{\circledR} 250 \mathrm{mg}$, dan kelompok 5 disebut sebagai kontrol negatif terdiri dari larutan $\mathrm{NaCl}$ 0,9\%. Selanjutnya dari setiap kelompok dilakukan replikasi sebanyak 3 kali untuk menjaga reliabilitasnya. 
Tabel 1. Pengamatan aktivitas cacing gelang (Ascaris lumbricoides) dengan pemberian esktrak etanol daun pinang yaki konsentrasi 5\%, 10\%, 20\%, larutan tablet Combantrin ${ }^{\circledR}$ (Kontrol Positif), dan larutan NaCl 0,9 \% (Kontrol Negatif)

\begin{tabular}{|c|c|c|c|c|c|}
\hline & \multirow[b]{2}{*}{ Ulangan } & \multicolumn{4}{|c|}{ Waktu Pengamatan (Jam) } \\
\hline & & Jam ke-6 & Jam ke-12 & Jam ke-18 & Jam ke-24 \\
\hline \multirow{4}{*}{$\begin{array}{c}\text { Ekstrak Etanol } \\
\text { Daun Pinang } \\
\text { Yaki } \\
5 \%\end{array}$} & I & $\begin{array}{c}\text { Gerakan } \\
\text { normal }\end{array}$ & $\begin{array}{c}\text { Gerakan } \\
\text { normal }\end{array}$ & $\begin{array}{l}\text { Gerakan } \\
\text { melambat }\end{array}$ & $\begin{array}{c}\text { Gerakan } \\
\text { melambat }\end{array}$ \\
\hline & II & $\begin{array}{c}\text { Gerakan } \\
\text { normal }\end{array}$ & $\begin{array}{c}\text { Gerakan } \\
\text { normal }\end{array}$ & $\begin{array}{l}\text { Gerakan } \\
\text { melambat }\end{array}$ & $\begin{array}{l}2 \text { Lisis dan } \\
1 \text { Gerakan } \\
\text { melambat }\end{array}$ \\
\hline & III & $\begin{array}{c}\text { Gerakan } \\
\text { normal }\end{array}$ & $\begin{array}{c}\text { Gerakan } \\
\text { normal }\end{array}$ & $\begin{array}{l}\text { Gerakan } \\
\text { melambat }\end{array}$ & $\begin{array}{c}1 \text { Lisis dan } \\
2 \text { Gerakan } \\
\text { melambat }\end{array}$ \\
\hline & I & $\begin{array}{c}\text { Gerakan } \\
\text { normal }\end{array}$ & $\begin{array}{c}\text { Gerakan } \\
\text { normal }\end{array}$ & $\begin{array}{l}\text { Gerakan } \\
\text { melambat }\end{array}$ & $\begin{array}{l}1 \text { Paralisis } \\
\text { dan } 2 \\
\text { Gerakan } \\
\text { melambat }\end{array}$ \\
\hline \multirow[t]{2}{*}{$\begin{array}{c}\text { Ekstrak Etanol } \\
\text { Daun Pinang } \\
\text { Yaki } \\
10 \%\end{array}$} & II & $\begin{array}{c}\text { Gerakan } \\
\text { normal }\end{array}$ & $\begin{array}{c}\text { Gerakan } \\
\text { normal }\end{array}$ & $\begin{array}{l}\text { Gerakan } \\
\text { melambat }\end{array}$ & $\begin{array}{l}1 \text { Paralisis } \\
\text { dan } 2 \\
\text { Gerakan } \\
\text { melambat }\end{array}$ \\
\hline & III & $\begin{array}{c}\text { Gerakan } \\
\text { normal }\end{array}$ & $\begin{array}{c}\text { Gerakan } \\
\text { normal }\end{array}$ & $\begin{array}{l}\text { Gerakan } \\
\text { melambat }\end{array}$ & $\begin{array}{l}1 \text { Paralisis } \\
\text { dan } 2 \\
\text { Gerakan } \\
\text { melambat }\end{array}$ \\
\hline \multirow{3}{*}{$\begin{array}{c}\text { Ekstrak Etanol } \\
\text { Daun Pinang } \\
\text { Yaki } \\
20 \%\end{array}$} & I & $\begin{array}{c}\text { Gerakan } \\
\text { normal }\end{array}$ & $\begin{array}{c}2 \text { Paralisis } \\
\text { dan } 1 \\
\text { Gerakan } \\
\text { melambat }\end{array}$ & 3 Lisis & - \\
\hline & II & $\begin{array}{c}\text { Gerakan } \\
\text { normal }\end{array}$ & $\begin{array}{c}\text { Gerakan } \\
\text { normal }\end{array}$ & $\begin{array}{l}\text { Gerakan } \\
\text { melambat }\end{array}$ & $\begin{array}{l}2 \text { Paralisis } \\
\text { dan } 1 \text { Lisis }\end{array}$ \\
\hline & III & $\begin{array}{c}\text { Gerakan } \\
\text { normal }\end{array}$ & $\begin{array}{l}\text { Gerakan } \\
\text { melambat }\end{array}$ & $\begin{array}{l}2 \text { Lisis dan } \\
1 \text { Gerakan } \\
\text { melambat }\end{array}$ & $\begin{array}{l}\text { Gerakan } \\
\text { melambat }\end{array}$ \\
\hline \multirow{3}{*}{$\begin{array}{l}\text { Kontrol Positif } \\
\text { Tablet } \\
\text { Combantrin }{ }^{\circledR} \\
250 \mathrm{mg}\end{array}$} & I & 3 Lisis & - & - & - \\
\hline & II & 3 Lisis & - & - & - \\
\hline & III & 3 Lisis & - & - & - \\
\hline \multirow{3}{*}{$\begin{array}{l}\text { Kontrol Negatif } \\
\mathrm{NaCl} 0,9 \%\end{array}$} & I & $\begin{array}{c}\text { Gerakan } \\
\text { normal }\end{array}$ & $\begin{array}{c}\text { Gerakan } \\
\text { normal }\end{array}$ & $\begin{array}{c}\text { Gerakan } \\
\text { normal }\end{array}$ & $\begin{array}{c}\text { Gerakan } \\
\text { normal }\end{array}$ \\
\hline & II & $\begin{array}{c}\text { Gerakan } \\
\text { normal }\end{array}$ & $\begin{array}{c}\text { Gerakan } \\
\text { normal }\end{array}$ & $\begin{array}{c}\text { Gerakan } \\
\text { normal }\end{array}$ & $\begin{array}{c}\text { Gerakan } \\
\text { normal }\end{array}$ \\
\hline & III & $\begin{array}{c}\text { Gerakan } \\
\text { normal }\end{array}$ & $\begin{array}{c}\text { Gerakan } \\
\text { normal }\end{array}$ & $\begin{array}{c}\text { Gerakan } \\
\text { normal }\end{array}$ & $\begin{array}{c}\text { Gerakan } \\
\text { normal }\end{array}$ \\
\hline
\end{tabular}


Hasil pengamatan uji efek antelmintik terhadap cacing gelang (Ascaris lumbricoides) yang dapat dilihat pada Tabel 1 menunjukkan efek yang berbeda-beda pada setiap konsentrasi ekstrak etanol daun pinang yaki, pirantel pamoat sebagai kontrol positif, dan $\mathrm{NaCl} 0,9 \%$ sebagai kontrol negatif. $\mathrm{NaCl} 0,9 \%$ merupakan larutan yang bersifat isotonis sehingga menjaga membran sel tubuh cacing agar tetap hidup. Selain itu, $\mathrm{NaCl} 0,9 \%$ mengandung ion-ion yang memang dibutuhkan oleh tubuh cacing untuk proses fisiologisnya. Oleh karena itu, $\mathrm{NaCl}$ 0,9\% digunakan sebagai kontrol negatif untuk membandingkan perbedaan efek yang ditimbulkan dari kelompok perlakuan.

Dapat dilihat dalam Tabel 1, pada ekstrak konsentrasi 5\%, pada jam ke 6 sampai jam ke 12 ekstrak etanol daun pinang yaki belum menunjukkan efek antelmintik yang dapat dilihat dengan gerakan cacing yang masih normal bergerak dalam cawan petri. Sedangkan pada jam ke 18, gerakan cacing mulai melambat, kemudian pada jam ke 24 sudah sampai mengalami lisis atau mati. Hal tersebut memperlihatkan bahwa zat dalam ekstrak etanol daun pinang yaki yang berkhasiat antelmintik sudah mulai mempengaruhi cacing tersebut. Selanjutnya mengenai hasil pengamatan pada konsentrasi 5\% yang berbeda-beda pada setiap pengulangannya diduga adanya perbedaan berat dan ukuran dari hewan uji yang digunakan karena hewan uji dimasukkan secara random ke dalam cawan petri. Selanjutnya ekstrak konsentrasi 10\% menunjukkan hasil yang konsisten pada setiap pengulangan dimana pada jam ke 6 sampai jam ke 12 gerakan cacing masih normal, pada jam ke 18 gerakan cacing melambat, dan pada jam ke 24 ada 1 cacing yang mengalami paralisis dan 2 cacing yang masih dalam gerakan lambat. Sehingga hal ini membuktikan bahwa zat yang berkhasiat antelmintik dalam ekstrak sudah mulai mempengaruhi cacing tersebut mulai dari jam ke 18. Berbeda dengan ekstrak konsentrasi $20 \%$ yang menunjukkan hasil yang tidak konsisten pada setiap pengulangannya seperti konsentrasi 5\% dimana pada jam ke 12 pada pengulangan pertama 1 cacing gerakannya sudah mulai melambat dan terdapat 2 cacing yang mengalami paralisis, selanjutnya pada jam ke 18 , semua cacing dalam cawan petri sudah mengalami lisis atau mati. Berbeda pada hasil pengamatan pengulangan kedua pada jam ke 12 cacing masih bergerak normal, kemudian cacing mulai menunjukkan gerakan melambat pada jam ke 18, dan akhirnya 2 cacing paralisis dan 1 cacing lisis atau mati pada jam ke 24 . Perbedaan lainnya pun terjadi pada pengulangan ketiga dimana pada jam ke 12 cacing sudah menunjukkan gerakan melambat dan pada jam ke 18 , terdapat 2 cacing yang mengalami lisis atau mati dan 1 gerakan melambat sampai pada jam ke 24. Perbedaan tersebut, masih diduga adanya perbedaan berat dan ukuran dari hewan uji yang digunakan karena hewan uji dimasukkan secara random ke dalam cawan petri. Selanjutnya, mengenai cacing yang mengalami paralisis atau kelumpuhan membuktikan bahwa cacing sudah mulai kehilangan fungsi otot pada bagian tubuh, dan cacing yang lisis atau mati dapat disebabkan karena senyawa tanin yang terkandung dalam ekstrak sudah menghambat kerja enzim dan mengganggu proses metabolisme pencernaan pada cacing sehingga cacing akan kekurangan nutrisi.

Pada kelompok kontrol positif yang menggunakan larutan tablet Combantrin ${ }^{\circledR}$ $250 \mathrm{mg}$ menunjukkan efek yang berbeda yaitu cacing mengalami lisis pada jam ke-6 secara konsisten pada setiap pengulangan atau replikasi, sehingga dapat dikatakan bahwa tablet Combantrin ${ }^{\circledR} 250 \mathrm{mg}$ memiliki efek antelmintik yang lebih cepat melumpuhkan bahkan membunuh cacing dibandingkan ekstrak etanol daun pinang yaki dalam konsentrasi yang digunakan yaitu 5\%, 10\%, dan $20 \%$. Hasil analisis menggunakan uji Kruskal Wallis menunjukkan hasil yang berbeda bermakna yaitu (sig. <0,05) sehingga terbukti adanya perbedaan efek yang ditimbulkan dari setiap konsentrasi pada kelompok perlakuan, kontrol positif, dan kontrol negatif. Selanjutnya analisis dilanjutkan dengan menggunakan uji 
Mann Whitney untuk melihat perbedaan efek antelmintik antara kelompok perlakuan yang diberikan ekstrak etanol daun pinang yaki dan kontrol positif yang diberikan larutan tablet Combantrin ${ }^{\circledR} 250 \mathrm{mg}$ sebagai obat pembanding menunjukkan hasil yang berbeda bermakna yaitu (sig. <0,05) antara ekstrak 5\% dan kontrol positif, selanjutnya antara ekstrak $10 \%$ dan kontrol positif juga menunjukkan hasil yang berbeda bermakna yaitu (sig. <0,05), sedangkan ekstrak 20\% dan kontrol positif menunjukkan hasil yang tidak berbeda bermakna yaitu (sig. >0,05) sehingga dapat dikatakan bahwa tidak ada perbedaan efek yang signifikan antara kedua kelompok tersebut. Hal tersebut disebabkan keduanya memiliki efek yang dapat melumpuhkan dan membunuh cacing atau dapat dikatakan juga membuat cacing tersebut lisis pada setiap pengulangan atau replikasi yang dilakukan.

Pirantel pamoat menimbulkan depolarisasi pada otot cacing dan meningkatkan frekuensi impuls, sehingga cacing mati dalam keadaan spastik (Syarif et al., 2007), sedangkan ekstrak etanol daun pinang yaki membunuh cacing dengan cara adanya senyawa tanin yang berkhasiat memberikan efek antelmintik sehingga cacing mengalami lisis. Tanin membunuh cacing dengan cara masuk ke dalam saluran pencernaan dan secara langsung mempengaruhi proses pembentukan protein yang dibutuhkan untuk aktivitas cacing (Setyohadi et al., 2014). Terdapat perbedaan kondisi kematian cacing yang dialami pada perlakuan ekstrak etanol daun pinang yaki $20 \%$ dan tablet Combantrin ${ }^{\circledR} \quad 250 \mathrm{mg}$ yang mengandung senyawa aktif pirantel pamoat, yaitu tubuh cacing dalam tablet Combantrin ${ }^{\circledR}$ $250 \mathrm{mg}$ setelah lisis terlihat kaku atau keras, sedangkan dalam ekstrak etanol daun pinang yaki $20 \%$ membran cacing terlihat rusak dan tidak kaku atau keras seperti dalam tablet Combantrin ${ }^{\circledR}$. Hal tersebut dapat terjadi karena tanin selain mampu menghambat enzim, tanin juga dapat merusak membran. Perbedaan waktu kematian cacing pun dapat terjadi karena perbedaan efek antara pemberian obat sintetik dalam hal ini mengandung senyawa aktif pirantel pamoat, dan pengobatan tradisional dengan tanaman obat dalam hal ini ekstrak etanol daun pinang yaki.

Tablet Combantrin ${ }^{\circledR} 250 \mathrm{mg}$ sebagai obat sintetik terbukti memiliki daya antelmintik yang lebih baik dari ekstrak etanol daun pinang yaki dalam konsentrasi yang digunakan dalam pengujian ini karena dapat melumpuhkan dan membunuh cacing dalam waktu yang lebih cepat. Ekstrak etanol daun pinang yaki 20\% juga terbukti memiliki daya antelmintik sebagai tanaman obat meskipun tidak dapat melumpuhkan dan membunuh cacing lebih cepat dibandingkan obat sintetik yang digunakan yaitu tablet Combantrin ${ }^{\circledR} 250 \mathrm{mg}$. Hal tersebut dapat terjadi karena konsentrasi yang digunakan dalam ekstrak etanol daun pinang yaki masih rendah jika dibandingkan dengan tablet Combantrin ${ }^{\circledR} 250 \mathrm{mg}$.

\section{KESIMPULAN}

Berdasarkan hasil penelitian yang telah dilakukan dapat disimpulkan bahwa ekstrak etanol daun pinang yaki (Areca vestiaria) memiliki pengaruh dalam memberikan efek antelmintik yang terbukti pada konsentrasi 5\%, $10 \%$, dan $20 \%$ yang dapat menyebabkan cacing mengalami paralisis sampai lisis. Pemberian Ekstrak 20\% dan kontrol positif menunjukkan hasil yang tidak berbeda bermakna yaitu (sig. >0,05) sehingga dapat dikatakan bahwa tidak ada perbedaan efek yang signifikan antara kedua kelompok tersebut.

\section{SARAN}

Berdasarkan hasil dan pembahasan efek antelmintik ekstrak etanol daun pinang yaki (Areca vestiaria), maka dapat diberikan saran yaitu perlu dilakukan penelitian lebih lanjut tentang uji efek antelmintik dengan konsentrasi ekstrak etanol daun pinang yaki (Areca vestiaria) yang lebih besar, dilakukan penelitian secara in vivo, menggunakan hewan uji dalam hal ini cacing yang berbeda dan sebaiknya dilakukan pengukuran tubuh hewan uji yang digunakan. 
DAFTAR PUSTAKA

Hamzah, A., M. Hambal, U. Balqis, Darmawi, Maryam, Rasmaidar. 2016 Aktivitas anthelmintik biji Veitchia merrillii terhadap Ascaridia galli secara in vitro. Trad Med J 21(22): 55-62

Katzung, B. G. 2004. Farmakologi Dasar dan Klinik. Salemba Empat, Jakarta

Kazura, J. W. 2007. Nematode Infections. In: Goldman L, Ausiello D, eds. Cecil Medicine. $23^{\text {rd }}$ ed. Philadelphia. Saunders Elsevier, Philadepphia

Ningsih, I. Y. 2016. Studi etnofarmasi penggunaan tumbuhan obat oleh suku tengger di Kabupaten Lumajang dan Malang, Jawa Timur. Phamacy 13(1): $10-20$

Setyohadi, R., Endharti A., Ulya N. 2014. Uji Daya Anthelmintik Ekstrak Etanol Daun Kumis Kucing (Orthosiphon aristatus) sebagai Anthelmintik terhadap Ascaris suum secara in vitro. Jurnal Kesehatan FKUB 3(1): 130-136

Simbala, H. E. I. 2007. Keanekaragaman Floristik Dan Pemanfaatannya Sebagai Tumbuhan Obat Di Kawasan Konservasi II Taman Nasional Bogani Nani Wartabone (Kabupaten Bolaang Mongondow Sulawesi Utara). IPB, Bogor

Soedarto. 2011. Buku ajar Parasitologi kedokteran. Sagung Seto, Jakarta

Syarif, A., P. Ascobat, E. Estuningtyas, R. Setiabudy, A. Setiawati, A. Muchtar. 2007. Farmakologi dan Terapi Edisi V. Gaya Baru, Jakarta

Syukron, M., I. Damriyasa, N. Suratma. 2014. Potensi Serbuk Daun Kelor (Moringa oleifera) Sebagai Anthelmintik Terhadap Infeksi Ascaris suum dan Feed Supplement pada Babi. Jurnal
Ilmu dan Kesehatan Hewan 2(2): $89-96$

Tiwow, D., W. Bodhi, N. Kojong. 2013. Uji Efek Antelmintik Ekstrak Etanol Biji Pinang (Areca cathechu) terhadap Cacing Ascaris lumbricoides dan Ascaridia galli secara in vitro. Pharmacon Jurnal Ilmiah Farmasi UNSRAT 2(2): 76 - 80

Tjay, T. H., K. Rahardja. 2002. Obat-obat Penting, Khasiat, Pengunaaan dan Efek Sampingnya, Edisi $V$. PT Elex Media Komputindo Kelompok Gramedia, Jakarta

World Health Organization (WHO). 2015. World Health Statistics 2015. WHO, Switzerland

World Health Organization (WHO). 2016. Weekly Epidemiological Record. WHO, Switzerland 